\title{
110th Anniversary: Near-Total Epoxidation Selectivity and Hydrogen Peroxide Utilization with Nb-EISA Catalysts for Propylene Epoxidation
}

\author{
Swarup K. Maiti, ${ }^{\dagger}$ Anand Ramanathan, ${ }^{\dagger}$ and Bala Subramaniam*, ${ }^{\dagger, \ddagger}$ \\ ${ }^{\dagger}$ Center for Environmentally Beneficial Catalysis, University of Kansas, Lawrence, Kansas 66047, United States \\ ${ }^{\ddagger}$ Department of Chemical and Petroleum Engineering, University of Kansas, Lawrence, Kansas 66045, United States
}

Supporting Information

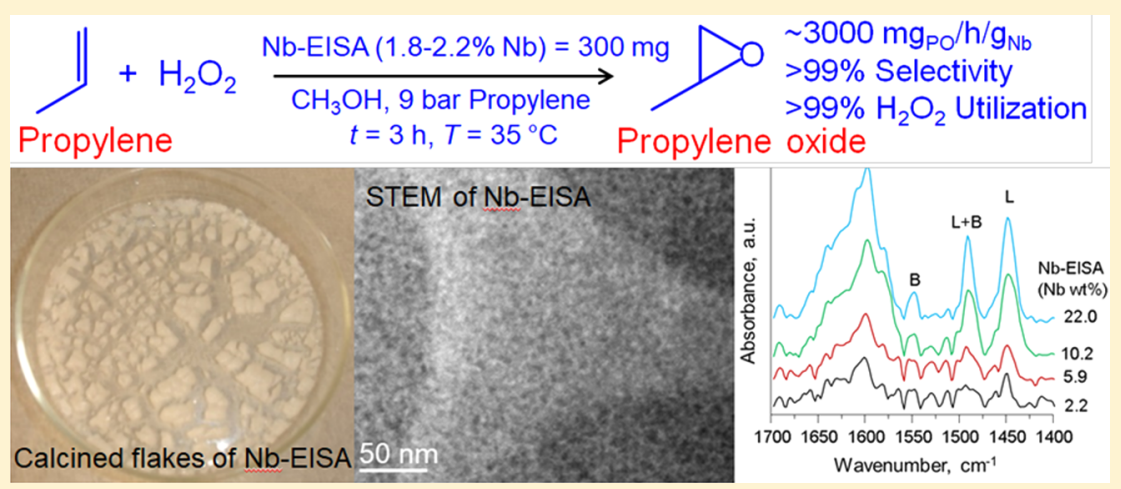

ABSTRACT: The Nb-EISA catalyst with relatively low $\mathrm{Nb}$ loadings ( $2 \mathrm{wt} \%$ ) shows exceptional propylene epoxidation performance with $\mathrm{H}_{2} \mathrm{O}_{2}$ as oxidant at $30-40{ }^{\circ} \mathrm{C}, 5-9$ bar propylene pressure with nearly total propylene oxide (PO) selectivity (>99\%), $\mathrm{H}_{2} \mathrm{O}_{2}$ utilization (>99\%) toward PO formation, high productivity ( $3200 \mathrm{mg} / \mathrm{h} / \mathrm{g}$ ), and mild $\mathrm{Nb}$ leaching (3-6\%). The predominantly Lewis acidic nature of the Nb-EISA catalysts favors epoxidation while their relatively low Brønsted acidity inhibits $\mathrm{H}_{2} \mathrm{O}_{2}$ decomposition and $\mathrm{Nb}$ leaching. At higher $\mathrm{Nb}$ loadings (8-17 wt \%), the catalytic performance deteriorates. However, significant performance improvements were achieved when the Nb-EISA materials are calcined in $\mathrm{N}_{2}$ (instead of air) during synthesis, depositing a carbon layer in the pores. The resulting pore hydrophobicity not only inhibits epoxide ring opening but also increases propylene concentration inside the pores resulting in higher $\mathrm{EO}$ productivity and lower $\mathrm{H}_{2} \mathrm{O}_{2}$ decomposition. The carbonized Nb-EISA materials also show improved stability to leaching.

\section{INTRODUCTION}

Propylene oxide (PO) is one of the most important chemical intermediates for producing many essential fine chemicals, such as polyurethane plastics, polyglycol esters, unsaturated resins, and surfactants. ${ }^{1-3}$ The global demand for PO is high, being $>10$ million metric tons/year in 2012 and growing at an annual rate of $5 \% .^{4,5}$ In general, $\mathrm{PO}$ is produced via epoxidation of propylene, an industrially significant substrate. Current commercial routes to PO production are mainly the chlorohydrin process, different hydroperoxide based processes, and the hydrogen peroxide propene oxide (HPPO) process. While the chlorohydrin process suffers from high environmental impact due to much waste generation, the hydroperoxide-based processes depend on stable byproduct (tertbutyl alcohol) value for economic viability. Among these processes, the HPPO process has less environmental impact as it produces only $\mathrm{H}_{2} \mathrm{O}$ as byproduct and uses mild operating conditions $\left(40-50{ }^{\circ} \mathrm{C}\right.$ and $20-30$ bar). The HPPO process provides a maximum $\mathrm{PO}$ selectivity of $95 \%$ using the titanium silicate (TS-1) catalyst $^{6-8}$ in methanol solvent. While the TS-1 catalyst is active, it is expensive and undergoes deactivation. ${ }^{9}$ Further, the extent to which $\mathrm{H}_{2} \mathrm{O}_{2}$ decomposes on the acidic TS- 1 catalyst is unknown. Stoichiometric utilization of $\mathrm{H}_{2} \mathrm{O}_{2}$ toward PO formation with near-complete $\mathrm{PO}$ selectivity is vital to making the process economically viable. Hence, there continues to be interest in alternative $\mathrm{PO}$ processes using inexpensive and robust catalysts that maximize $\mathrm{PO}$ selectivity and $\mathrm{H}_{2} \mathrm{O}_{2}$ utilization.

Various catalysts have been investigated for propylene epoxidation with hydrogen peroxide, including heteropolyacids, ${ }^{10,11}$ methyltrioxorhenium (MTO), ${ }^{9}$ tungsten based homogeneous catalysts, ${ }^{12}$ and various titanium containing zeolites, viz., Ti-MWW ${ }^{13}$ and $\mathrm{TiCl}_{4}$-modified HZSM-5, ${ }^{14}$ in addition to TS-1. ${ }^{6-8}$ For example, $\mathrm{Xi}$ et al. performed propylene epoxidation ${ }^{10}$ at $65{ }^{\circ} \mathrm{C}$ using in situ formed $\mathrm{H}_{2} \mathrm{O}_{2}$

Received: June 27, 2019

Revised: August 28, 2019

Accepted: September 2, 2019

Published: September 2, 2019 
with $85 \%$ PO yield in a $6 \mathrm{~h}$ batch run. The catalyst, $[\pi$ $\left.\mathrm{C}_{5} \mathrm{H}_{5} \mathrm{NC}_{16} \mathrm{H}_{33}\right]_{3}\left[\mathrm{PO}_{4}\left(\mathrm{WO}_{3}\right)_{4}\right]$, used in this system is insoluble but can form a soluble active species in the presence of $\mathrm{H}_{2} \mathrm{O}_{2}$. When the $\mathrm{H}_{2} \mathrm{O}_{2}$ is consumed, the catalyst precipitates enabling easy recycling. Lee et al. developed a liquid phase propylene epoxidation process ${ }^{9}$ using the MTO catalyst under mild operating conditions similar to those of the HPPO process producing PO with $98 \%$ yield and complete $\mathrm{H}_{2} \mathrm{O}_{2}$ utilization for PO formation. In contrast, most of the Ti-based heterogeneous catalysts show lower $\mathrm{H}_{2} \mathrm{O}_{2}$ utilization toward PO formation compared to MTO. For example, the $\mathrm{H}_{2} \mathrm{O}_{2}$ utilization toward PO formation is reported to be $94 \%$ and 96\% respectively over Ti-MCM-42 and Ti-MWW catalysts. These Ti-based catalysts are often tedious and expensive to synthesize. Similar to $\mathrm{Ti}, \mathrm{Nb}-{ }^{15-30}$ and $\mathrm{W}$-based catalysts ${ }^{21,29}$ are also active for olefin epoxidation using $\mathrm{H}_{2} \mathrm{O}_{2}$ as oxidant. However, in studies of liquid-phase ethylene epoxidation with $\mathrm{H}_{2} \mathrm{O}_{2}$, we found that metal leaching is a major problem being more severe for $\mathrm{W}^{29}$ in general compared to Nb-based silicates. $^{21}$

The epoxidation activity of $\mathrm{Nb}$-silicates is in general attributed to the presence of well dispersed $\mathrm{Nb}(\mathrm{V})$ sites in tetrahedral coordination. We demonstrated recently that improved $\mathrm{Nb}$ dispersion can be achieved using the Evaporation Induced Self-Assembly (EISA) synthesis method with relatively low Brønsted acidity. The Nb-EISA catalysts show remarkable activity for cyclohexene epoxidation with high epoxidation selectivity compared to $\mathrm{Nb}$-catalysts prepared by either one-pot or impregnation methods. ${ }^{31}$ Further, carbonization of the $\mathrm{Nb}$-EISA catalyst ${ }^{31}$ via calcination in the presence of $\mathrm{N}_{2}$ remarkably stabilizes the epoxide from ring opening reactions while also improving $\mathrm{H}_{2} \mathrm{O}_{2}$ utilization toward epoxide formation.

Invariably almost all reported epoxidation studies with $\mathrm{Nb}$ based catalysts involve substrates such as cyclohexene, cyclooctene, limonene, and vegetable oil that are liquids at ambient conditions. Our work addresses the important question of how these epoxidation catalysts fare in the case of a lower olefin such as propylene that requires higher pressures to ensure adequate solubility in the liquid phase. As propylene $\left(P_{\mathrm{c}}=46 \mathrm{bar}, T_{\mathrm{c}}=92.2 \pm 0.8{ }^{\circ} \mathrm{C}\right)$ is close to its critical temperature at ambient conditions, it dissolves significantly in the liquid phase containing methanol (as in the HPPO process and our experiments) depending on the pressure. This causes the volume of the liquid phase to change with pressure, which must be experimentally quantified to reliably design experiments and to interpret the results. In the only reported study of $\mathrm{Nb}$-based heterogeneous catalyst for liquid phase epoxidation of propylene, such important details are not addressed. ${ }^{32}$

Motivated by the foregoing considerations, we report here systematic investigations of Nb-EISA catalysts and their carbonized versions, $\mathrm{C}-\mathrm{Nb}$-EISA, for propylene epoxidation under similar operating conditions as those employed in the HPPO process. Remarkably, the Nb-EISA catalysts show exceptional propylene epoxidation activity, stability, and $\mathrm{H}_{2} \mathrm{O}_{2}$ utilization compared to $\mathrm{Nb}$-silicates prepared by other one-pot and impregnation methods. Optimized Nb-EISA catalysts perform significantly better for propylene epoxidation than $\mathrm{Ti}$ based catalysts providing $>99 \%$ epoxide selectivity and $\mathrm{H}_{2} \mathrm{O}_{2}$ utilization.

\section{EXPERIMENTAL SECTION}

2.1. Materials. Triblock copolymer (Pluronic P123, $\mathrm{EO}_{20}-$ $\mathrm{PO}_{70}-\mathrm{EO}_{20}$, with an average molecular weight $\sim 5,800$, Aldrich), ethanol (Absolute, 200 Proof, Acros organics), methanol (Sigma-Aldrich), tetraethyl orthosilicate (TEOS) (98\% Acros organics), conc. hydrochloric acid (37\%, Fisher), and niobium(V) chloride (Alfa Aesar) were used as received. Acetonitrile (HPLC grade, 99.9\%, Fisher) and $\mathrm{H}_{2} \mathrm{O}_{2}$ (50 wt \% in water, Fisher) were used as received for catalytic propylene epoxidation with $\mathrm{H}_{2} \mathrm{O}_{2}$. Ferroin indicator solution, ceric sulfate $(0.1 \mathrm{~N})$, and trace metal grade sulfuric acid (99.9 wt \%) were purchased from Fischer Scientific and used as received. The PO standard, 1-methoxy-2-propanol, and propylene glycol were purchased from Sigma-Aldrich, whereas 2-methoxy-1propanol was purchased from Chem-Bridge Chemical. Propylene was purchased from Matheson Tri-Gas Co (polymer grade).

2.2. Synthesis of Nb-EISA and Catalyst Characterization. The Nb-EISA catalysts were prepared as described previously. ${ }^{31}$ Briefly, TEOS was added to the acidified ethanolic solution containing P123, followed by the required amounts of niobium(V) chloride predissolved in ethanol. After stirring the mixture for a couple of hours, it is transferred to a Pyrex Petri dish, and the solvent is allowed to evaporate for 24 days. The resulting rigid flakes were then calcined in either flowing air or nitrogen at $550{ }^{\circ} \mathrm{C}$ for $5 \mathrm{~h}$ at a heating rate of 1.5 ${ }^{\circ} \mathrm{C} / \mathrm{min}$ to obtain either $\mathrm{Nb}$-EISA or $\mathrm{Nb}$-EISA, respectively. The calcined samples were characterized with a comprehensive suite of complementary analytical techniques including SAXS, $\mathrm{XRD}, \mathrm{XRF}, \mathrm{N}_{2}$ physisorption, diffuse reflectance UV-vis spectroscopy, transmission electron microscopy (TEM, SEM), $\mathrm{NH}_{3}$-TPD, and FTIR of adsorbed pyridine. ${ }^{3}$

The metal contents in the fresh and spent solid catalysts were determined by inductively coupled plasma optical emission spectrometry (ICP-OES). Prior to analysis, the catalyst $(60 \mathrm{mg})$ was digested in the presence of HF $(2 \mathrm{~g})$, $\mathrm{H}_{2} \mathrm{SO}_{4}(3 \mathrm{~g})$, and deionized water $(5 \mathrm{~g})$ in an autoclave at 100 ${ }^{\circ} \mathrm{C}$ for $3 \mathrm{~h}$. The resulting solutions were analyzed by the ICPOES technique using appropriate calibration standards. The ICP-OES analysis offers high sensitivity in calculating metal concentrations in the catalysts $( \pm 1.6 \mathrm{ppm}$ for $\mathrm{Nb}$ and \pm 0.78 ppm for $\mathrm{Si}$ ).

2.3. Volumetric Expansion Studies. When pressurized propylene is dissolved in methanol, it shows enhanced solubility resulting in propylene-expanded liquids. A $50 \mathrm{~mL}$ high-pressure Jerguson cell rated to $\sim 400$ bar at $100{ }^{\circ} \mathrm{C}^{33}$ was used for volumetric expansion studies. Either pure methanol or a methanol $+50 \% \mathrm{H}_{2} \mathrm{O}_{2} / \mathrm{H}_{2} \mathrm{O}$ mixture is placed in the view cell which is then submerged in a constant temperature bath. To facilitate the mixing of cell contents, the loaded liquid is agitated by a piston. Once the desired temperature is attained, propylene is pumped as a liquid from an ISCO pump into the cell to the desired pressure. Mixing of the gas and liquid phases by a piston expedites the attainment of equilibrium (as inferred from constant $\mathrm{P}$ and $\mathrm{T}$ ). At equilibrium, the volume of a propylene expanded liquid phase is measured visually on a calibrated external linear scale.

2.4. Catalytic Epoxidation Studies. The catalysts were tested for propylene epoxidation in a semibatch mode in a 50 $\mathrm{mL}$ Parr reactor equipped with a magnetically driven stirrer, pressure transducer, and thermocouple. Reactor details and the operating procedure are described elsewhere, ${ }^{21}$ and a 
schematic of the reactor unit is given in the Supporting Information (Figure S1). In a typical reaction, a mixture containing a $50 \%$ aqueous $\mathrm{H}_{2} \mathrm{O}_{2}(10 \mathrm{mmol})$ solution, $\mathrm{MeOH}$ $(625 \mathrm{mmol})$, acetonitrile $(3 \mathrm{mmol})$ as internal standard, and a solid catalyst (fresh or spent) was loaded into the Parr reactor. A blank experiment using 1,2-dimethoxyethane (DME) as internal standard confirmed the inertness of acetonitrile. The solution was heated with mild stirring to attain the desired temperature $\left(35^{\circ} \mathrm{C}\right)$. Thereafter, propylene was charged from an external reservoir pressurizing the reactor up to $0.9 \mathrm{MPa}$. The impeller speed was kept at $1400 \mathrm{rpm}$ to eliminate gasliquid mass transfer limitations. Isothermal semibatch reactions lasting up to $3 \mathrm{~h}$ were performed at constant pressure. The liquid-phase reaction mixture was analyzed by online GC to determine the concentrations of the desired product (PO) and the byproducts [1-methoxy-2-propanol (1M2P), 2-methoxy-1propanol (2M1P), and propylene glycol (PG)]. The following definitions are used in evaluating the performance of the tested catalysts

$$
\begin{gathered}
P_{\mathrm{PO}}=\frac{m_{\mathrm{PO}}}{(\text { batchtime })\left(m_{\text {metal }}\right)} \\
S_{\mathrm{PO}}=\left(\frac{n_{\mathrm{PO}}}{n_{\mathrm{PO}}+n_{1 \mathrm{M} 2 \mathrm{P}}+n_{2 \mathrm{M} 1 \mathrm{P}}+n_{\mathrm{PG}}}\right) \times 100 \% \\
U_{\mathrm{H}_{2} \mathrm{O}_{2}}=\frac{n_{\mathrm{PO}}+n_{1 \mathrm{M} 2 \mathrm{P}}+n_{2 \mathrm{M} 1 \mathrm{P}}+n_{\mathrm{PG}}}{n_{\mathrm{H}_{2} \mathrm{O}_{2}}^{0}-n_{\mathrm{H}_{2} \mathrm{O}_{2}}} \times 100 \% \\
X_{\mathrm{H}_{2} \mathrm{O}_{2}}=\frac{n_{\mathrm{H}_{2} \mathrm{O}_{2}}^{0}-n_{\mathrm{H}_{2} \mathrm{O}_{2}}}{n_{\mathrm{H}_{2} \mathrm{O}_{2}}^{0}} \times 100 \%
\end{gathered}
$$

where $P_{\mathrm{PO}}, S_{\mathrm{PO}}, U_{\mathrm{H}_{2} \mathrm{O}_{2}}$ and $X_{\mathrm{H}_{2} \mathrm{O}_{2}}$ denote $\mathrm{PO}$ productivity (mg PO h ${ }^{-1} \mathrm{~g}^{-1}$ metal), PO selectivity, $\mathrm{H}_{2} \mathrm{O}_{2}$ utilization toward PO formation, and $\mathrm{H}_{2} \mathrm{O}_{2}$ conversion, respectively; $m_{\mathrm{PO}}$ and $m_{\text {metal }}$ represent the mass of $\mathrm{PO}$ formed and the mass of metal in the catalyst, respectively; $n_{\mathrm{PO}}, n_{1 \mathrm{M} 2 \mathrm{P}}, n_{2 \mathrm{M} 1 \mathrm{P}}$, and $n_{\mathrm{PG}}$ denote the molar amounts of PO, 1M2P, 2M1P, and PG formed, respectively; and $n_{\mathrm{H}_{2} \mathrm{O}_{2}}^{0}$ and $n_{\mathrm{H}_{2} \mathrm{O}_{2}}$ denote the initial and the final molar amounts of $\mathrm{H}_{2} \mathrm{O}_{2}$, respectively.

\section{RESULTS AND DISCUSSION}

3.1. Catalyst Characterization. Detailed physicochemical characterization of $\mathrm{Nb}$-EISA samples and their carbonized versions ( $\mathrm{C}-\mathrm{Nb}$-EISA) may be found in the Supporting Information (Figures S2-S9) and elsewhere. ${ }^{31}$ Only the salient features are summarized here. The mesoporous nature of $\mathrm{Nb}$-EISA and C-Nb-EISA samples was confirmed by $\mathrm{N}_{2}$ sorption revealing typical type IV isotherm and $\mathrm{H}_{2}$ hysteresis. The physicochemical characteristics are summarized in Table 1. For $\mathrm{Nb}$-EISA and $\mathrm{C}-\mathrm{Nb}$-EISA samples, the surface area ranges from 615 to $680 \mathrm{~m}^{2} / \mathrm{g}$ and from 418 to $571 \mathrm{~m}^{2} / \mathrm{g}$, respectively, decreasing with increased $\mathrm{Nb}$ content (1.6-22.0 wt \%). These materials possess an average pore diameter of about $2.7-3.4 \mathrm{~nm}$. Further, the total acidity $(0.10-0.31 \mathrm{mmol}$ $\mathrm{NH}_{3} / \mathrm{g}$ ) was found to be lower compared to other $\mathrm{Nb}$ containing mesoporous silicates. Although an increase in the relative amounts of Lewis acid sites was inferred from the FTIR spectra of adsorbed pyridine, relatively low amounts of Brønsted acid sites were observed (Table 1). Further, the weak Brønsted acidity is confirmed by complete desorption of

\begin{tabular}{|c|c|c|c|c|c|c|c|}
\hline no. & catalyst & $\begin{array}{c}\mathrm{Nb} \\
\text { wt } \%^{a}\end{array}$ & $\underset{\text { wt }}{\mathrm{C}}{ }^{b}$ & $\begin{array}{c}S_{\mathrm{BET}}^{c} \\
\left(\mathrm{~m}^{2} / \mathrm{g}\right)\end{array}$ & $\begin{array}{c}V_{\mathrm{tp}}^{d} \\
\left(\mathrm{~cm}^{3} / \mathrm{g}\right)\end{array}$ & $\begin{array}{c}d_{\mathrm{P}, \mathrm{BJH}}{ }^{e} \\
(\mathrm{~nm})\end{array}$ & $\begin{array}{c}\text { acidity } \\
\mathrm{NH}_{3} \\
(\mathrm{mmol} / \mathrm{g})\end{array}$ \\
\hline 1 & $\begin{array}{l}\mathrm{Nb}- \\
\text { EISA }\end{array}$ & 1.8 & & 680 & 0.45 & 3.0 & 0.10 \\
\hline 2 & & 3.7 & & 618 & 0.46 & 3.4 & 0.18 \\
\hline 3 & & 6.0 & & 962 & 1.11 & 4.6 & 0.18 \\
\hline 4 & & 10.2 & & 681 & 0.54 & 3.4 & 0.24 \\
\hline 5 & & 22.0 & & 615 & 0.47 & 3.4 & 0.31 \\
\hline 6 & $\begin{array}{c}\mathrm{C}-\mathrm{Nb}- \\
\text { EISA }\end{array}$ & 1.6 & 16.5 & 571 & 0.40 & 2.9 & 0.06 \\
\hline 7 & & 3.3 & 21.5 & 473 & 0.36 & 2.9 & 0.12 \\
\hline 8 & & 7.8 & 23.4 & 426 & 0.41 & 3.2 & 0.18 \\
\hline 9 & & 16.6 & 24.7 & 418 & 0.37 & 3.2 & 0.22 \\
\hline 10 & $\begin{array}{l}\text { Nb- } \\
\text { EISA }^{f}\end{array}$ & 1.9 & & 557 & 0.36 & 2.7 & $\mathrm{ND}^{j}$ \\
\hline 11 & $\begin{array}{l}\text { Nb- } \\
\text { EISA }^{g}\end{array}$ & 1.8 & & 549 & 0.35 & 2.7 & $\mathrm{ND}^{j}$ \\
\hline 12 & $\begin{array}{l}\text { Nb- } \\
\text { EISA }^{h}\end{array}$ & 1.4 & & 512 & 0.32 & 2.7 & $\mathrm{ND}^{j}$ \\
\hline 13 & $\begin{array}{c}\mathrm{C}-\mathrm{Nb}- \\
\text { EISA }^{i}\end{array}$ & 1.4 & $\mathrm{NM}^{i}$ & 555 & 0.41 & 2.9 & $\mathrm{ND}^{j}$ \\
\hline
\end{tabular}
pyridine at mild temperature $\left(250{ }^{\circ} \mathrm{C}\right)$. Diffuse reflectance
Table 1. Physical Properties of Nb-EISA and C-Nb-EISA Catalysts

${ }^{a}{ }_{\text {wt }} \%$ in sample determined by XRF. ${ }^{b}$ wt $\%$ in sample determined by TG/DTA. ${ }^{c} S_{\mathrm{BET}}=\mathrm{BET}$ specific surface area from adsorption isotherm at $P / P_{0}$ between 0.05 and $0.30 .{ }^{d} V_{t \mathrm{P}}=$ total pore volume at $0.99 \mathrm{P} / \mathrm{P}_{0}$. ${ }^{e} d_{\mathrm{P}, \mathrm{BJH}}=$ average pore diameter calculated from adsorption branch of $\mathrm{N}_{2}$ isotherms using the BJH model. ${ }^{f}$ Another batch of Nb-EISA $(1.9 \%) .{ }^{g}$ After $10 \mathrm{~h}$ reaction. ${ }^{h}$ After 4 recycle runs. ${ }^{i} \mathrm{NM}=$ not measured. ${ }^{j} \mathrm{ND}=$ not determined.

UV-vis characterization reveals the presence of bands at 200$204 \mathrm{~nm}$ attributed to ligand-to-metal charge transfer in isolated $\mathrm{NbO}_{4}$ tetrahedra and another band at 242-267 $\mathrm{nm}$ due to oligomeric $\mathrm{NbO}_{x}$ tetrahedral. ${ }^{31}$ The lack of a band at 290-320 $\mathrm{nm}$ implies the absence of bulk $\mathrm{Nb}_{2} \mathrm{O}_{5}$ species which is also evidenced from powder XRD patterns.

3.2. Volumetric Expansion Studies. While conventional liquid phases are noncompressible, gas-expanded liquid phases are compressible. The compressibility depends on the extent of gas dissolution in the liquid phase. Hence, volumetric expansion data are important to calculate the propylene concentration in the liquid phase precisely. Such data also facilitate reliable interpretation of the effects of various parameters such as temperature, propylene pressure, and aqueous $\mathrm{H}_{2} \mathrm{O}_{2}$ concentration on the extent of dissolution of propylene in the liquid phase. As shown in Figure 1, the volume of initial liquid phase containing either pure methanol or a representative reaction mixture (containing methanol and

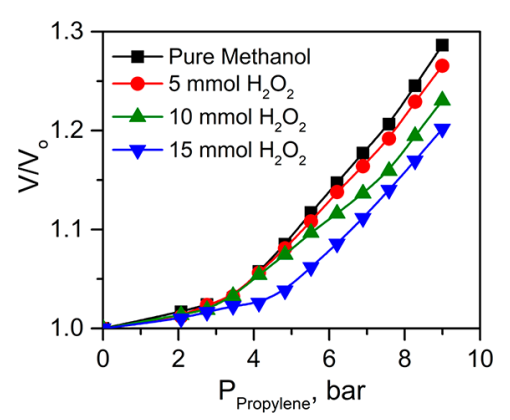

Figure 1. Volumetric expansion plot with propylene pressure at 35 ${ }^{\circ} \mathrm{C}$. 
Table 2. Performances of Nb-EISA with Different $\mathrm{Nb}$ Loadings and Reaction Times for Propylene Epoxidation ${ }^{b}$

\begin{tabular}{|c|c|c|c|c|c|c|c|c|}
\hline no. & $\mathrm{Nb}$-EISA, $\mathrm{Nb}$ wt $\%$ & time $(\mathrm{h})$ & $Y_{\mathrm{PO}}(\mathrm{mmol})( \pm 3 \%)$ & $P_{\mathrm{PO}}( \pm 3 \%)$ & $S_{\mathrm{EO}} \%( \pm 3 \%)$ & $X_{\mathrm{H}_{2} \mathrm{O}_{2}} \%( \pm 3 \%)$ & $U_{\mathrm{H}_{2} \mathrm{O}_{2}} \%( \pm 3 \%)$ & leaching $\%( \pm 5 \%)$ \\
\hline 1 & $1.8^{a}$ & 3 & 0.63 & 2340 & $>99$ & 5.3 & $>99$ & 3.5 \\
\hline 2 & 3.7 & 3 & 1.20 & 2071 & $>99$ & 12.7 & 94.5 & 5.4 \\
\hline 3 & 6.0 & 3 & 2.84 & 3050 & $>99$ & 28.7 & 96.3 & 9.3 \\
\hline 4 & 10.2 & 3 & 1.23 & 777 & 91.8 & 22.7 & 59.0 & 13.7 \\
\hline 5 & 22.0 & 3 & 0.84 & 247 & 86.6 & 31.5 & 31.1 & 4.5 \\
\hline 6 & $2.0^{a}$ & 3 & 0.94 & 3171 & $>99$ & 9.1 & $>99$ & 3.5 \\
\hline 7 & $2.0^{a}$ & 10 & 2.85 & 2900 & $>99$ & 27.9 & $>99$ & 5.7 \\
\hline 8 & $1.9^{a}$ & 3 & 0.93 & 3174 & $>99$ & 9.3 & $>99$ & 3.3 \\
\hline
\end{tabular}

${ }^{a}$ Different batches with similar Nb loadings. ${ }^{b}$ Reaction conditions: $\mathrm{MeOH}=624 \mathrm{mmol}, \mathrm{H}_{2} \mathrm{O}_{2}=10 \mathrm{mmol}, \mathrm{AN}=3 \mathrm{mmol}$, catalyst loading $=300$ $\mathrm{mg}, T=35^{\circ} \mathrm{C}$, propylene $P=9$ bar (maintained constant), $1400 \mathrm{rpm}$.

$50 \%$ aqueous $\mathrm{H}_{2} \mathrm{O}_{2}$ ) increases with increasing propylene pressure, implying increased propylene dissolution in the liquid phase. At a fixed temperature, the extent of volumetric expansion decreases with increasing $\mathrm{H}_{2} \mathrm{O}_{2}$ concentration in the methanol $+\mathrm{H}_{2} \mathrm{O}_{2}$ (50\% aqueous) mixture. At $35{ }^{\circ} \mathrm{C}$ and $9 \mathrm{bar}$ propylene pressure, the volumetric expansion in the case of pure methanol is $29 \%$. In the case of methanol $+\mathrm{H}_{2} \mathrm{O}_{2}$ (aqueous) mixtures, the volumetric expansion caused by propylene dissolution at 9 bar and $35{ }^{\circ} \mathrm{C}$ is $27 \%, 23 \%$, and $20 \%$ when the $\mathrm{H}_{2} \mathrm{O}_{2}$ contents in the mixture are 5,10 , and 15 mmol, respectively. As expected, increased concentrations of polar $\mathrm{H}_{2} \mathrm{O}_{2}$ in the liquid phase decrease the solubility of nonpolar propylene. Even though the main product, $\mathrm{PO}$, was not included in the volumetric expansion studies, PO formation during reaction $(3 \mathrm{~h})$ constitutes only $\sim 0.8$ wt \% of the reaction mixture and, hence, is not expected to alter the propylene dissolution significantly.

3.3. Epoxidation of Propylene. 3.3.1. Epoxidation of Propylene by $\mathrm{Nb}$-EISA Catalysts. Nb-EISA catalysts with different $\mathrm{Nb}$ loadings were screened for propylene epoxidation, and the results are summarized in Table 2 (entries 1-5). The $\mathrm{Nb}$-EISA catalyst with $1.8 \mathrm{wt} \% \mathrm{Nb}$ loading displayed nearly total $S_{\mathrm{PO}}(>99 \%)$ and $U_{\mathrm{H}_{2} \mathrm{O}_{2}}(>99 \%)$ with relatively low $\mathrm{Nb}$ leaching (3.5\%) during a $3 \mathrm{~h}$ run. With an increase in $\mathrm{Nb}$ loading up to $10.2 \mathrm{wt} \%$, the yield of PO increased and then decreased at the high $\mathrm{Nb}$ loading of $22 \mathrm{wt} \% . U_{\mathrm{H}_{2} \mathrm{O}_{2}}$ values also decreased with increased $\mathrm{Nb}$ loading. The decreases in $P_{\mathrm{PO}}$ and $U_{\mathrm{H}_{2} \mathrm{O}_{2}}$ values at the higher $\mathrm{Nb}$ loadings are attributed to the formation of oligomeric $\mathrm{NbOx}$ species that are not as active as the isolated $\mathrm{NbOx}$ species for epoxidation. Further, the Brønsted acidic nature of the oligomeric $\mathrm{NbOx}$ species also decomposes $\mathrm{H}_{2} \mathrm{O}_{2}$, adversely affecting its utilization for PO formation.

We prepared different batches of Nb-EISA materials with similar $\mathrm{Nb}$ loadings (1.9-2.0 wt \%) and tested for catalyst stability during extended runs (Table 2, entries 6-8). Similar $P_{\mathrm{PO}}$ was observed for the extended run $(10 \mathrm{~h})$ suggesting that the catalyst is stable under the reaction conditions. Further, the decreased $\mathrm{Nb}$ leaching $(5.7 \%$ at $10 \mathrm{~h}$ vs $3.5 \%$ at $3 \mathrm{~h}$ ) does not scale with reaction time suggesting that the leaching decreases with time. Additionally, Nb-EISA catalysts prepared in two different batches with almost identical $\mathrm{Nb}$ loadings show similar catalytic activities (Table 2, entries 6 and 8) under similar reaction conditions. This indicates that the catalyst synthesis technique is reproducible for similar $\mathrm{Nb}$ loadings.

We also tested various mesoporous $\mathrm{Nb}$-silicate catalysts (viz., Nb-KIT-5, Nb-KIT-6, and Nb-TUD-1) that were active for ethylene epoxidation. ${ }^{21,29}$ As shown in Table 3 (entry 1),
Table 3. Performances of Different Nb-Silicates for Propylene Epoxidation ${ }^{b}$

$\begin{array}{cccccccc}\text { no. } & \text { catalyst } & \begin{array}{c}\mathrm{Nb} \\ \text { wt } \%\end{array} & \begin{array}{c}P_{\mathrm{PO}} \\ ( \pm 3 \%)\end{array} & \begin{array}{c}S_{\mathrm{EO}} \% \\ ( \pm 3 \%)\end{array} & \begin{array}{c}\mathrm{X}_{\mathrm{H}_{2} \mathrm{O}_{2}} \% \\ ( \pm 3 \%)\end{array} & \begin{array}{c}U_{\mathrm{H}_{2} \mathrm{O}_{2}} \% \\ ( \pm 3 \%)\end{array} & \begin{array}{c}\text { leaching } \\ \%( \pm 5 \%)\end{array} \\ \begin{array}{c}\text { Nb- } \\ \text { KIT-5 }\end{array} & 2.2 & 2500 & 88 & 15.6 & 70 & 10.3 \\ \begin{array}{c}\text { Nb- } \\ \text { TUD-1 }\end{array} & 3.8 & 4075 & >99 & 27.1 & 89.4 & 20.9 \\ 3 & \begin{array}{c}\text { Nb- } \\ \text { TUD- } \\ 1^{a}\end{array} & 3.8 & 3329 & >99 & 26.3 & 74.6 & 22.2 \\ 4 & \begin{array}{c}\text { Nb- } \\ \text { TUD-1 } \\ \text { Bn-Nb- } \\ \text { TUD-1 }\end{array} & 2.7 & 11680 & >99 & 17.0 & 80.1 & 24.8 \\ & 907 & >99 & 4.1 & 93.6 & 3.6\end{array}$

${ }^{a}$ Reaction temperature is $40{ }^{\circ} \mathrm{C} .{ }^{b}$ Reaction conditions: $\mathrm{MeOH}=624$ mmol, $\mathrm{H}_{2} \mathrm{O}_{2}=10 \mathrm{mmol}, \mathrm{AN}=3 \mathrm{mmol}$, catalyst loading $=300 \mathrm{mg}, T$ $=35^{\circ} \mathrm{C}$, propylene $P=9$ bar (maintained constant), $t=3 \mathrm{~h}, 1400$ rpm.

Nb-KIT-5 (2.2 wt \% Nb) exhibits moderate PO productivity $\left(P_{\mathrm{PO}}\right)(2500 \mathrm{mg} / \mathrm{h} / \mathrm{g})$ and $\mathrm{PO}$ selectivity $\left(S_{\mathrm{PO}}\right)(88 \%)$. The $\mathrm{H}_{2} \mathrm{O}_{2}$ utilization efficiency $\left(\mathrm{U}_{\mathrm{H}_{2} \mathrm{O}_{2}}\right)$ is $70 \%$, and the $\mathrm{Nb}$ leaching during the $3 \mathrm{~h}$ run was $10.3 \%$. In contrast, Nb-TUD-1 (0.83.8 wt \%) displayed higher $P_{\mathrm{PO}}(4,075-11,680 \mathrm{mg} / \mathrm{h} / \mathrm{g})$ and PO selectivity $\left(S_{\mathrm{PO}}>99 \%\right)$ with moderate to high $U_{\mathrm{H}_{2} \mathrm{O}_{2}}(75-$ $90 \%)$ values. However, the leaching of $\mathrm{Nb}$-TUD-1 catalysts $(20-24 \%)$ was more severe compared to Nb-KIT-5 (10\%). In the case of Nb-TUD-1 with $3.8 \mathrm{wt} \% \mathrm{Nb}$ loading, an increase in temperature (from 308 to $313 \mathrm{~K}$ ) decreases $P_{\mathrm{PO}}$ from 4,075 to $3,329 \mathrm{mg} / \mathrm{h} / \mathrm{g}$ and $U_{\mathrm{H}_{2} \mathrm{O}_{2}}$ from $89.4 \%$ to $74.6 \%$, probably due to the decrease of propylene concentration in the liquid phase and/or $\mathrm{H}_{2} \mathrm{O}_{2}$ decomposition (Table 3, entries 2 and 3). At even lower $\mathrm{Nb}$ loadings ( $0.8 \mathrm{wt} \%), P_{\mathrm{PO}}$ was significantly enhanced to $11,680 \mathrm{mg} / \mathrm{h} / \mathrm{g}$. This is attributed to the dominant presence of Lewis acid sites compared to Brønsted acid sites at low $\mathrm{Nb}$ loadings. ${ }^{21}$ However, the $\mathrm{Nb}$ leaching $(\sim 25 \%)$ was still significant. Bn-Nb-TUD-1, ${ }^{30}$ prepared by covalent capping of benzyl groups on Nb-TUD-1 (3.8 wt \% $\mathrm{Nb}$ ), displayed a better performance than that of the uncapped catalyst with dramatically reduced metal leaching from $21 \%$ to $3.6 \%$. However, this capped catalyst showed almost 4-fold less PO productivity (907 vs $4075 \mathrm{mg} / \mathrm{h} / \mathrm{g}$ ) attributed to the reduction of Lewis acid sites during the passivation step. ${ }^{21}$ In contrast, the $\mathrm{Nb}$-EISA catalysts show nearly total epoxide selectivity and $\mathrm{H}_{2} \mathrm{O}_{2}$ utilization with significantly lower $\mathrm{Nb}$ leaching (Table 2). This enhanced performance is attributed to the predominance of Lewis acid sites with relatively low Brønsted acidity in the $\mathrm{Nb}$-EISA catalysts. 
Table 4. Effect of Temperature, Pressure, $\mathrm{H}_{2} \mathrm{O}_{2}$ Concentration, and Catalyst Loading for Propylene Epoxidation over Nb-EISA $\left(2.0\right.$ wt \% Nb) ${ }^{c}$

\begin{tabular}{|c|c|c|c|c|c|c|c|c|c|c|}
\hline no. & $\begin{array}{c}\mathrm{T} \\
\left({ }^{\circ} \mathrm{C}\right)\end{array}$ & $\begin{array}{c}P \\
\text { (bar) }\end{array}$ & $\begin{array}{c}\mathrm{H}_{2} \mathrm{O}_{2} \\
(\mathrm{mmol})\end{array}$ & $\begin{array}{c}\text { catalyst amt } \\
(\mathrm{mg})\end{array}$ & $\begin{array}{l}Y_{\mathrm{PO}} \mathrm{mmol} \\
( \pm 3 \%)\end{array}$ & $\begin{array}{c}P_{\mathrm{PO}} \\
( \pm 3 \%)\end{array}$ & $\begin{array}{l}S_{\mathrm{EO}} \% \\
( \pm 3 \%)\end{array}$ & $\begin{array}{c}X_{\mathrm{H}_{2} \mathrm{O}_{2}} \% \\
( \pm 3 \%)\end{array}$ & $\begin{array}{l}U_{\mathrm{H}_{2} \mathrm{O}_{2}} \% \\
( \pm 3 \%)\end{array}$ & $\begin{array}{c}\text { leaching } \% \\
( \pm 5 \%)\end{array}$ \\
\hline 1 & 30 & 9 & 10 & 300 & 0.48 & 1618 & $>99$ & 4.67 & $>99$ & 5.2 \\
\hline 2 & 35 & 9 & 10 & 300 & 0.94 & 3171 & $>99$ & 9.08 & $>99$ & 3.1 \\
\hline 3 & 40 & 9 & 10 & 300 & 0.83 & 2809 & $>99$ & 8.28 & 97.1 & 4.9 \\
\hline 4 & 45 & 9 & 10 & 300 & 0.58 & 1964 & $>99$ & 9.04 & 65.2 & 4.0 \\
\hline 5 & 35 & 7 & 10 & 300 & 0.48 & 1618 & $>99$ & 4.67 & $>99$ & 5.2 \\
\hline 6 & 35 & 5 & 10 & 300 & 0.30 & 1032 & $>99$ & 3.0 & $>99$ & 4.0 \\
\hline 7 & 35 & $20^{a}$ & 10 & 300 & 0.97 & 3232 & $>98$ & 11.4 & 86 & $\mathrm{NM}^{b}$ \\
\hline 8 & 35 & 9 & 5 & 300 & 0.22 & 733 & $>99$ & 2.2 & $>99$ & 1.5 \\
\hline 9 & 35 & 9 & 15 & 300 & 1.41 & 4776 & $>99$ & 11.7 & 80.1 & 4.0 \\
\hline 10 & 35 & 9 & 10 & 150 & 0.47 & 3188 & $>99$ & 4.5 & $>99$ & 5.2 \\
\hline 11 & 35 & 9 & 10 & 600 & 1.21 & 2052 & $>99$ & 11.4 & $>99$ & 3.6 \\
\hline 12 & 35 & 9 & 10 & 900 & 1.54 & 1760 & $>99$ & 14.7 & $>99$ & 3.8 \\
\hline
\end{tabular}

${ }^{a} 9$ bar propylene and 11 bar $\mathrm{N}_{2} \cdot{ }^{b} \mathrm{NM}=$ not measured. ${ }^{c}$ Reaction conditions: $\mathrm{MeOH}=624 \mathrm{mmol}, \mathrm{AN}=3$ mmol, propylene $P=$ maintained constant, $t=3 \mathrm{~h}, 1400 \mathrm{rpm}$.

Parametric studies including temperature, propylene pressure, $\mathrm{H}_{2} \mathrm{O}_{2}$ concentration, and catalyst loading were performed with the $\mathrm{Nb}$-EISA catalyst with $2 \mathrm{wt} \% \mathrm{Nb}$, the best-performing catalyst (Table 2). Table 4 summarizes temperature effects. When the reaction temperature is increased from 30 to $35^{\circ} \mathrm{C}$, the PO yield increased approximately 2 -fold. Notably, both PO selectivity and $\mathrm{H}_{2} \mathrm{O}_{2}$ utilization remained high (>99\%) at 35 ${ }^{\circ} \mathrm{C}$. However, at higher temperatures $\left(40\right.$ and $\left.45^{\circ} \mathrm{C}\right)$, both PO productivity and $\mathrm{H}_{2} \mathrm{O}_{2}$ utilization efficiency decreased. The lower activity at higher temperatures (40 and $45{ }^{\circ} \mathrm{C}$ ) is attributed to the lower propylene dissolution in the gasexpanded liquid phase as well as increased $\mathrm{H}_{2} \mathrm{O}_{2}$ decomposition, resulting in decreased availability of the two key reactants.

At $35^{\circ} \mathrm{C}$, PO yield increases with propylene pressure. At 35 ${ }^{\circ} \mathrm{C}$, the $\mathrm{PO}$ yields are $0.30,0.48$, and $0.94 \mathrm{mmol}$ at propylene pressures of 5, 7, and 9 bar, respectively (Table 4, entries 2, 5, and 6). Notably, nearly total (>99\%) $S_{\mathrm{PO}}$ and $U_{\mathrm{H}_{2} \mathrm{O}_{2}}$ were achieved in this pressure range, and $\mathrm{Nb}$ leaching remained low (within 3-4\%). The increased PO yield at higher propylene pressures is attributed to enhanced propylene solubility in the methanolic liquid phase (Figure 2). Given that propylene at 35 ${ }^{\circ} \mathrm{C}$ is below its critical temperature $\left(92.2 \pm 0.8{ }^{\circ} \mathrm{C}\right)$, pressurization with $\mathrm{N}_{2}$ beyond the saturation vapor pressure would cause propylene condensation and dissolution in the liquid phase. For example, when propylene at 9 bar was pressurized with 11 bar of $\mathrm{N}_{2}$ at $35^{\circ} \mathrm{C}$, the PO yield increased approximately $10 \%$ more (Table 4 , entries 2 and 7 ).

The effect of $\mathrm{H}_{2} \mathrm{O}_{2}$ concentration was also studied. As inferred in Table 4 (entries 2, 8, and 9), PO productivity increased significantly with an increase in $\mathrm{H}_{2} \mathrm{O}_{2}$ concentration. However, $\mathrm{Nb}$ leaching also increased. While negligible $\mathrm{H}_{2} \mathrm{O}_{2}$ decomposition was observed when 5 or $10 \mathrm{mmol}$ of $\mathrm{H}_{2} \mathrm{O}_{2}$ was used, significant $\mathrm{H}_{2} \mathrm{O}_{2}$ decomposition occurred when $15 \mathrm{mmol}$ of $\mathrm{H}_{2} \mathrm{O}_{2}$ was used.

When the catalyst loading is increased by 2 -fold (from 150 to $300 \mathrm{mg}$, entries 10 and 2 in Table 4), the PO yield doubled, resulting in similar PO productivity. However, when the catalyst loading was further increased by 4 - and 6-fold (from $150 \mathrm{mg}$ to 600 and $900 \mathrm{mg}$, entries 10-12), the corresponding increases in PO yield were $2.6 \times$ and $3.2 \times$, respectively. These are also reflected in the lower PO productivity at higher catalyst loadings (beyond $300 \mathrm{mg}$ ). Thus, lower temperature

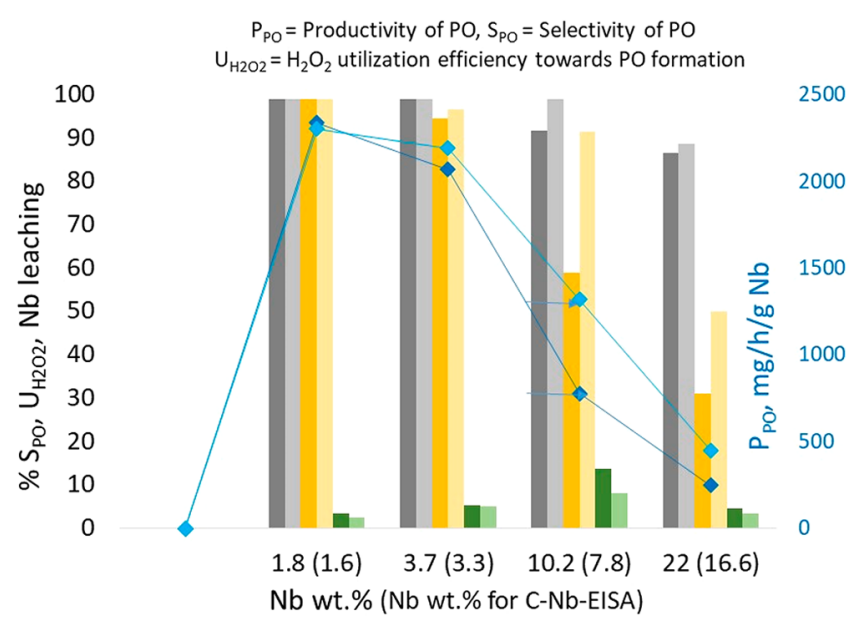

$\begin{array}{llcc} & \text { Nb-EISA, } \mathrm{S}_{\mathrm{PO}} & \text { C-Nb-EISA, } \mathrm{S}_{\mathrm{PO}} & \text { Nb-EISA, } \mathrm{U}_{\mathrm{H} 2 \mathrm{O} 2} \\ & \text { C-Nb-EISA, } \mathrm{U}_{\mathrm{H} 2 \mathrm{O} 2} & \text { Nb-EISA, Nb leaching } & \text { C-Nb-EISA, Nb leaching } \\ -\quad & \text { C-Nb-EISA, } \mathrm{P}_{\mathrm{PO}} \rightarrow \quad \text { Nb-EISA, } \mathrm{P}_{\mathrm{PO}} & \end{array}$

Figure 2. Comparative epoxidation performances of Nb-EISA catalysts and its carbonized versions (C-Nb-EISA) at different $\mathrm{Nb}$ loadings.

$\left(\sim 35{ }^{\circ} \mathrm{C}\right)$, lower $\mathrm{Nb}$ loadings $(\sim 2$ wt $\%)$, and moderate propylene pressure $(\sim 9$ bar $)$ are preferred to maximize PO productivity and $\mathrm{H}_{2} \mathrm{O}_{2}$ utilization while minimizing $\mathrm{Nb}$ leaching. Figure 2 compares key performance measures of the $\mathrm{Nb}$-EISA catalyst and its carbonized version at different $\mathrm{Nb}$ loadings. The figure more clearly displays how carbonized $\mathrm{Nb}$ EISA (C-Nb-EISA) catalysts show better catalytic performance than neat $\mathrm{Nb}$-EISA, becoming more prominent at higher $\mathrm{Nb}$ loadings.

3.3.2. Epoxidation of Propylene by Carbonized Nb-EISA Catalysts (C-Nb-EISA). In order to improve $\mathrm{H}_{2} \mathrm{O}_{2}$ utilization and epoxide selectivity at higher $\mathrm{Nb}$ loadings, the assynthesized Nb-EISA materials were carbonized by calcination in the presence of $\mathrm{N}_{2}$ (rather than air) at $550{ }^{\circ} \mathrm{C}$. As expected, the $\mathrm{C}-\mathrm{Nb}$-EISA (carbonized version of $\mathrm{Nb}$-EISA) catalysts showed better $P_{\mathrm{PO}}, \mathrm{S}_{\mathrm{PO}}, U_{\mathrm{H}_{2} \mathrm{O}_{2}}$, and resistance to metal leaching compared to Nb-EISA with similar Nb loadings (Table 5). For the $\mathrm{Nb}$-EISA catalyst with 10.2 wt $\% \mathrm{Nb}$, the values of $P_{\mathrm{PO}}$, $\mathrm{S}_{\mathrm{PO}}, U_{\mathrm{H}_{2} \mathrm{O}_{2}}$, and $\mathrm{Nb}$ leaching were $777 \mathrm{mg} / \mathrm{h} / \mathrm{g}, 92 \%, 59 \%$, and 
Table 5. Performances of C-Nb-EISA with Different $\mathrm{Nb}$ Loadings and Reaction Times for Propylene Epoxidation ${ }^{a}$

$\begin{array}{cccccccc} & \begin{array}{c}\text { C-Nb- } \\ \text { EISA, } \\ \text { no. }\end{array} & \begin{array}{c}Y_{\mathrm{PO}} \\ \mathrm{Nmol} \% \\ ( \pm 3 \%)\end{array} & \begin{array}{c}P_{\mathrm{PO}} \\ ( \pm 3 \%)\end{array} & \begin{array}{c}S_{\mathrm{EO}} \% \\ ( \pm 3 \%)\end{array} & \begin{array}{c}X_{\mathrm{H}_{2} \mathrm{O}_{2}} \% \\ ( \pm 3 \%)\end{array} & \begin{array}{c}U_{\mathrm{H}_{2} \mathrm{O}_{2}} \% \\ ( \pm 3 \%)\end{array} & \begin{array}{c}\text { leaching } \\ \% \\ ( \pm 5 \%)\end{array} \\ 1 & 1.6 & 0.55 & 2305 & >99 & 5.3 & >99 & 2.4 \\ 2 & 3.3 & 1.12 & 2193 & >99 & 11.2 & 96.7 & 5.0 \\ 3 & 7.8 & 1.60 & 1320 & >99 & 16.7 & 91.4 & 8.0 \\ 4 & 16.6 & 1.16 & 450 & 88.7 & 26.7 & 50.0 & 3.5\end{array}$

${ }^{a}$ Reaction conditions: $\mathrm{MeOH}=624 \mathrm{mmol}, \mathrm{H}_{2} \mathrm{O}_{2}=10 \mathrm{mmol}$, $\mathrm{AN}=3$ mmol, catalyst loading $=300 \mathrm{mg}, T=35^{\circ} \mathrm{C}$, propylene $P=9$ bar (maintained constant), $1400 \mathrm{rpm}$.

$13.7 \%$, respectively (Table 2 , entry 3 ), compared to $1320 \mathrm{mg} /$ $\mathrm{h} / \mathrm{g},>99 \%, 91 \%$, and $8 \%$ observed with C-Nb-EISA catalysts with 7.8 wt $\% \mathrm{Nb}$ (Table 5, entry 3 ). We hypothesize that carbonization of the silica matrix induces pore hydrophobicity ${ }^{34}$ which in turn enhances the propylene concentration in the pores, ${ }^{35}$ resulting in higher propylene epoxidation rates. Further, pore hydrophobicity reduces the concentration of polar molecules such as water inside the pores and therefore mitigates the formation of Brønsted acid sites, a causative factor for $\mathrm{H}_{2} \mathrm{O}_{2}$ decomposition over $\mathrm{Nb}$ silicates. ${ }^{21}$ Although the percentage of leached species decreases at the highest $\mathrm{Nb}$ loading (16.6 wt \%), the absolute amount of $\mathrm{Nb}$ leached from this catalyst is more or less the same as the catalyst with 7.8 wt $\% \mathrm{Nb}$ loading. The population of oligomeric $\mathrm{NbOx}$ species (inactive for epoxidation) is progressively greater in catalysts with higher $\mathrm{Nb}$ loadings. The oligomeric species are more susceptible to leaching compared to the isolated $\mathrm{NbOx}$ species although the rate of leaching appears to taper off at higher loadings.

3.3.3. Catalyst Stability. Recycle tests with the $\mathrm{Nb}$-EISA catalyst with 1.9 wt \% $\mathrm{Nb}$ loading were carried out up to four cycles (Table 6, entries 1-5). Notably, a slightly improved PO productivity $\left(P_{\mathrm{PO}}\right)$ was achieved in the first recycle run compared to the first run with a fresh catalyst. Interestingly, after the first recycle run, $P_{\mathrm{PO}}$ remained almost unchanged during the subsequent recycle runs. Nearly total PO selectivity and $\mathrm{H}_{2} \mathrm{O}_{2}$ utilization were observed with steady but low $\mathrm{Nb}$ leaching $(\sim 6 \mathrm{wt} \%)$ during the recycle runs. The increased PO productivity during the first recycle run may be attributed to the leaching of extra framework $\mathrm{NbOx}$ species that are not as active as the framework $\mathrm{Nb}$ species. The carbonized version, $\mathrm{C}-\mathrm{Nb}$-EISA with 1.55 wt \% $\mathrm{Nb}$ loading, showed similar trends during four recycle runs (Table 6 entries 6-10), confirming that both $\mathrm{Nb}$-EISA and its carbonized version are recyclable catalysts.

During allyl alcohol epoxidation with hydrogen peroxide, both Ti-MCM-41 and Ti-SBA-15 showed Ti leaching as well as partial collapse of the mesoporous structure. ${ }^{36,37}$ The fresh $\mathrm{Nb}$-EISA and $\mathrm{C}-\mathrm{Nb}$-EISA catalysts along with the corresponding spent catalysts after the fourth recycle run and after a $10 \mathrm{~h}$ extended run were analyzed by the $\mathrm{N}_{2}$ physisorption method. As inferred from Table 1 (entries 9-12), no significant changes between the fresh and spent catalysts were observed in the nitrogen physisorption isotherms and pore size distribution, confirming that the catalysts are structurally stable under reaction conditions. Further, no evidence of Si leaching was observed in the spent reaction mixtures providing complementary evidence that the $\mathrm{Nb}$ leaching is not due to a loss of the structural integrity of the siliceous support during the reaction. These observations thus clearly demonstrate that inducing hydrophobicity in the pores not only enhances epoxidation rates but also inhibits leaching. This provides guidance for future work in developing new catalyst synthesis methods to achieve optimum hydrophobicity that minimizes catalyst leaching to practically viable levels.

3.4. Proposed Mechanism for Propylene Epoxidation. Recently, our group ${ }^{21}$ and collaborators ${ }^{38}$ conducted mechanistic investigations of liquid phase ethylene epoxidation by aqueous hydrogen peroxide catalyzed by niobium silicate. Density functional theory calculations were used to investigate catalytic pathways ${ }^{38}$ and probable reasons ${ }^{21}$ for hydrogen peroxide decomposition and potential metal leaching. In the present work, the propylene epoxidation was performed under reaction conditions similar to ethylene epoxidation ${ }^{21,38}$ using a similar type of $\mathrm{Nb}$ incorporated mesoporous silicate as catalyst. We therefore hypothesize that the ethylene epoxidation mechanism can be extended to propylene epoxidation as well. Scheme 1 shows plausible mechanistic pathways for propylene epoxidation based on previous studies. ${ }^{21,38}$

A five-step cycle is proposed. The initial steps consist of adsorption of hydrogen peroxide to the $\mathrm{Nb}$ center followed by coordination of propylene to the $\mathrm{H}_{2} \mathrm{O}_{2}$, resulting in the formation of $\mathrm{Nb}$-hydroperoxide. The $\mathrm{H}_{2} \mathrm{O}_{2}$ coordinated propylene then undergoes epoxidation via an oxygen atom transfer from the hydroperoxide moiety to the $\mathrm{C}=\mathrm{C}$ bond of propylene via a transition state. $^{39}$ The epoxidation proceeds preferentially as a direct attack of the nucleophilic olefin on an

Table 6. Recycle Study of Nb-EISA (1.9 wt \% Nb) and C-Nb-EISA (1.6 wt \% Nb) for Propylene Epoxidation ${ }^{b}$

\begin{tabular}{|c|c|c|c|c|c|c|c|c|c|}
\hline no. & cycle $^{a}$ & catalyst amt (mg) & $\mathrm{Nb}$ wt $\%$ & $Y_{\mathrm{PO}} \mathrm{mmol}( \pm 3 \%)$ & $P_{\mathrm{PO}}( \pm 3 \%)$ & $S_{\mathrm{EO}} \%( \pm 3 \%)$ & $X_{\mathrm{H}_{2} \mathrm{O}_{2}} \%( \pm 3 \%)$ & $U_{\mathrm{H}_{2} \mathrm{O}_{2}} \%( \pm 3 \%)$ & leaching $\%( \pm 5 \%)$ \\
\hline 1 & $\mathrm{Nb}$-EISA & 300 & 1.88 & 0.926 & 3274 & $>99$ & 9.3 & $>99$ & 6.3 \\
\hline 2 & $\mathrm{R} 1$ & 284 & 1.66 & 1.143 & 4682 & $>99$ & 11.3 & 97.7 & 6.7 \\
\hline 3 & $\mathrm{R} 2$ & 278 & 1.55 & 1.103 & 4960 & $>99$ & 10.8 & $>99$ & 5.7 \\
\hline 4 & R3 & 256 & 1.46 & 0.873 & 4525 & $>99$ & 8.6 & $>99$ & 5.2 \\
\hline 5 & R4 & 245 & 1.38 & 0.748 & 4279 & $>99$ & 7.5 & $>99$ & 5.8 \\
\hline 6 & $\mathrm{C}-\mathrm{Nb}$-EISA & 300 & 1.55 & 0.552 & 2305 & $>99$ & 5.3 & $>99$ & 2.4 \\
\hline 7 & $\mathrm{R} 1$ & 278 & 1.51 & 0.434 & 2000 & $>99$ & 4.3 & $>99$ & 3.8 \\
\hline 8 & $\mathrm{R} 2$ & 264 & 1.45 & 0.390 & 1864 & $>99$ & 3.9 & $>99$ & 3.7 \\
\hline 9 & R3 & 253 & 1.40 & 0.393 & 2152 & $>99$ & 3.8 & $>99$ & 3.4 \\
\hline 10 & $\mathrm{R} 4$ & 241 & 1.35 & 0.331 & 1973 & $>99$ & 3.3 & $>99$ & 3.6 \\
\hline
\end{tabular}

a"R\#" stands for recycle run, and the \# (1-4) represents the corresponding number of the recycle run. ${ }^{b}$ Reaction conditions: MeOH $=624$ mmol, $\mathrm{AN}=3 \mathrm{mmol}, T=35^{\circ} \mathrm{C}$, propylene $P=9$ bar (maintained constant), $t=3 \mathrm{~h}, 1400 \mathrm{rpm}$. 
Scheme 1. Proposed Mechanism for Propylene Epoxidation Using Aqueous Hydrogen Peroxide as Oxidant ${ }^{a}$

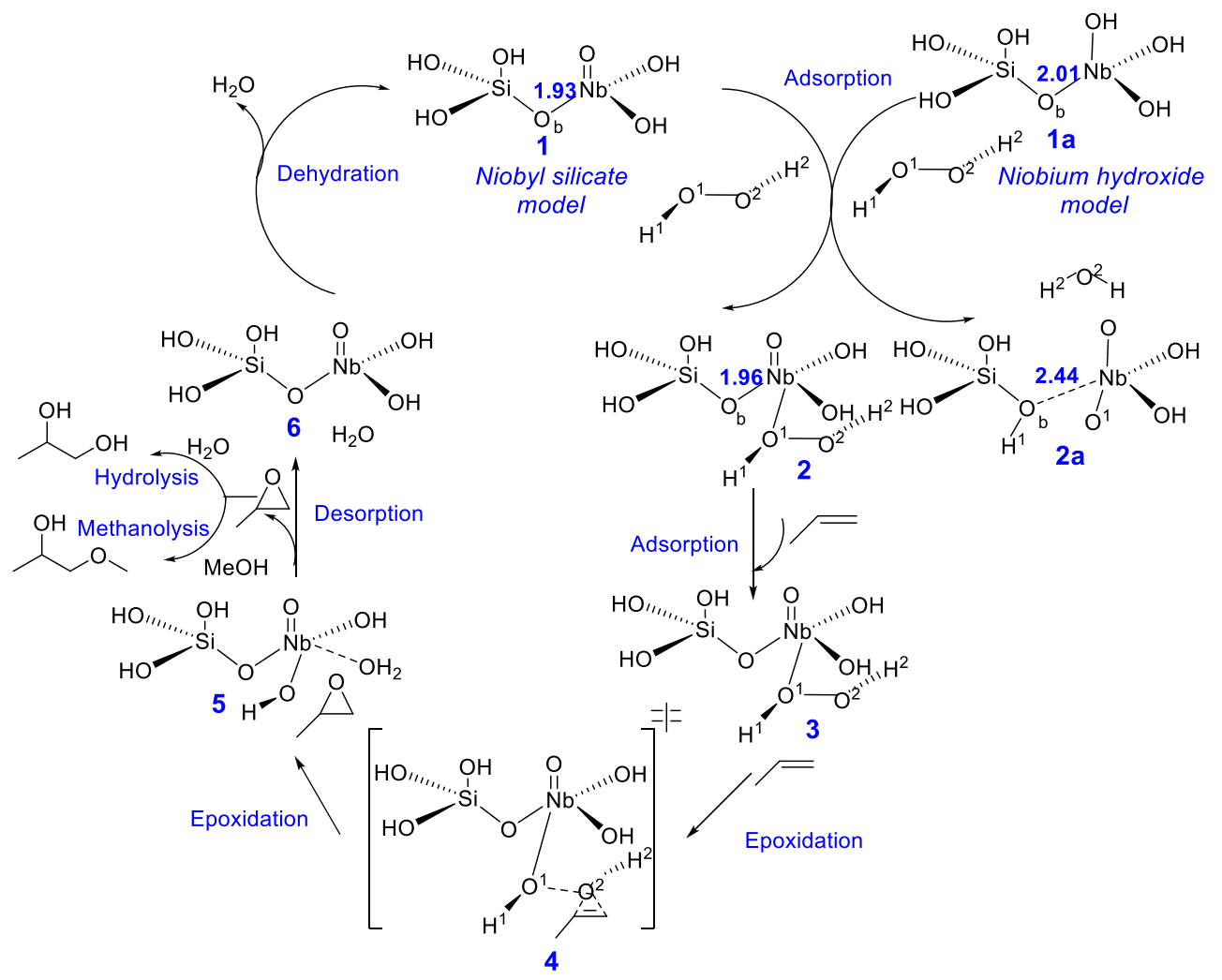

${ }^{a}$ All bond distances are in $\AA$.

electrophilic peroxo oxygen center via a transition state of spiro structure (Sharpless mechanism). Propylene epoxidation follows an electrophilic mechanism in which the $\pi_{\mathrm{C}=\mathrm{C}}$ bond of the alkene transfers electrons to the $\sigma_{\mathrm{O}-\mathrm{O}} *$ peroxo antibond of the $\mathrm{Nb}$-hydroperoxide intermediate and accepts electrons from the $\pi^{*}$ orbital of peroxo oxygen into its (alkene's) $\pi^{*}$ orbital. This electron donation process elongates the $\mathrm{O}-\mathrm{O}$ bond and eventually leads to its cleavage to form the corresponding epoxide. The epoxidation step to form propylene oxide is the rate-limiting step. The subsequent steps involve desorption of the propylene oxide product followed by dehydration to regenerate the catalyst. If methanol is used as solvent, the propylene oxide can further undergo hydrolysis and solvolysis reactions to form the corresponding byproducts, propylene glycol and isomers of methoxy propanol, respectively. The extent of byproduct formation depends on the Brønsted acidity of the catalyst and the process conditions. In general, higher Brønsted acidity, temperature, and water content enhance byproduct formation.

It is noteworthy that the reaction of the niobium silicate structure with $\mathrm{H}_{2} \mathrm{O}_{2}$ was modeled in different orientations ${ }^{21}$ in order to understand the mechanism of $\mathrm{H}_{2} \mathrm{O}_{2}$ adsorption (step 1 in Scheme 1), potential $\mathrm{H}_{2} \mathrm{O}_{2}$ decomposition, and metal leaching. The computational model suggested that Brønsted acidity can induce $\mathrm{H}_{2} \mathrm{O}_{2}$ decomposition and metal leaching. According to the model, when $\mathrm{H}_{2} \mathrm{O}_{2}$ is adsorbed on a Lewis acidic site $(\mathrm{Nb}=\mathrm{O}$, niobyl silicate model, compound $\mathbf{1}$ in Scheme 1) in the perpendicular orientation, the process is less exothermic with $\Delta H=-9.1 \mathrm{kcal} / \mathrm{mol}(-12.4 \mathrm{kcal} / \mathrm{mol}$ for the parallel orientation). However, the model could not predict a pathway for $\mathrm{H}_{2} \mathrm{O}_{2}$ decomposition when it is bound to niobyl silicate indicating that Lewis acidic sites show no $\mathrm{H}_{2} \mathrm{O}_{2}$ decomposition.

In contrast, when $\mathrm{H}_{2} \mathrm{O}_{2}$ is adsorbed on a Brønsted acidic site $(\mathrm{Nb}-\mathrm{OH}$, niobium hydroxide model, compound 1a in Scheme $1)$, it readily undergoes decomposition in a highly exothermic process $(\Delta H=-52.0 \mathrm{kcal} / \mathrm{mol})$, breaking the $\mathrm{O}^{1}-\mathrm{O}^{2}$ bond and forming water through extraction of the hydroxyl proton to $\mathrm{O}^{2}$ (compound 2a, Scheme 1). This process transfers $\mathrm{H}^{1}$ proton from the $\mathrm{O}^{1}$ of $\mathrm{H}_{2} \mathrm{O}_{2}$ to the bridging oxygen $\left(\mathrm{O}_{\mathrm{b}}\right)$. Dissociation of the $\mathrm{O}_{b}-\mathrm{Nb}$ bond (via bond elongation) leads to $\mathrm{Nb}$ leaching. Clearly, the ideal catalyst should display predominant Lewis acidity to favor epoxidation and minimal Brønsted acidity to reduce $\mathrm{H}_{2} \mathrm{O}_{2}$ decomposition and metal leaching. In order to reduce the Brønsted acidity, we hypothesized that catalysts with relatively low $\mathrm{Nb}$ content should have more isolated $\mathrm{Nb}$ sites (Lewis acid sites) with reduced Brønsted acid sites. A catalyst synthetic technique such as the Evaporation Induced Self-Assembly (EISA) method has been reported to provide improved metal dispersion with relatively low Brønsted acidity. ${ }^{31}$ The fact that the Nb-EISA catalysts with enhanced Lewis acidity and reduced Brønsted acidity clearly improves epoxidation yield with reduced leaching lends credence to this proposed mechanism.

\section{CONCLUSIONS}

$\mathrm{Nb}$-EISA catalysts with low $\mathrm{Nb}$ loadings (<2 wt \%) exhibit excellent activity for propylene epoxidation displaying virtually total PO selectivity and $\mathrm{H}_{2} \mathrm{O}_{2}$ utilization toward $\mathrm{PO}$ formation with much reduced $\mathrm{Nb}$ leaching compared to $\mathrm{Nb}$ silicates prepared by impregnation and/or hydrothermal synthesis techniques. This excellent performance is attributed to the 
presence of predominantly Lewis acid sites with significantly lower Brønsted acid sites. However, on $\mathrm{Nb}$-EISA catalysts with higher $\mathrm{Nb}$ loadings ( $>3.7$ wt \%), the $\mathrm{PO}$ selectivity and $\mathrm{H}_{2} \mathrm{O}_{2}$ utilization decrease with increased $\mathrm{Nb}$ leaching. This deterioration in performance is attributed to increases, albeit low, in Brønsted acidity at reaction conditions. Carbonized versions of the $\mathrm{Nb}$-EISA improve the performance of such catalysts by increasing pore hydrophobicity that enhances propylene concentration in the pores while inhibiting polar molecules, especially water and the resultant formation of Brønsted acid sites. The Nb-EISA and its carbonized version are both stable and recyclable catalysts. These insights pave the way for rational design of improved propylene epoxidation catalysts.

\section{ASSOCIATED CONTENT}

\section{S Supporting Information}

The Supporting Information is available free of charge on the ACS Publications website at DOI: 10.1021/acs.iecr.9b03461.

Schematic of experimental unit and figures for characterization of $\mathrm{Nb}$-EISA and $\mathrm{C}-\mathrm{Nb}$-EISA (carbonized version) catalyst samples (PDF)

\section{AUTHOR INFORMATION}

\section{Corresponding Author}

*Phone: +1-785-864-2903. Fax: +1-785-864-6051. E-mail: bsubramaniam@ku.edu.

\section{ORCID}

Bala Subramaniam: 0000-0001-5361-1954

\section{Notes}

The authors declare no competing financial interest.

\section{ACKNOWLEDGMENTS}

This work was supported by a grant from the joint National Science Foundation and Environmental Protection Agency program Networks for Sustainable Material Synthesis and Design (NSF-EPA 1339661).

\section{REFERENCES}

(1) Nijhuis, T. A.; Makkee, M.; Moulijn, J. A.; Weckhuysen, B. M. The Production of Propylene Oxide: Catalytic Processes and Recent Developments. Ind. Eng. Chem. Res. 2006, 45, 3447-3459.

(2) Climent, M. J.; Corma, A.; Iborra, S. Heterogeneous Catalysts for the One-Pot Synthesis of Chemicals and Fine Chemicals. Chem. Rev. 2011, 111, 1072-1133.

(3) Hayashi, T.; Tanaka, K.; Haruta, M. Selective Vapor-Phase Epoxidation of Propylene over $\mathrm{Au} / \mathrm{TiO}_{2}$ Catalysts in the Presence of Oxygen and Hydrogen. J. Catal. 1998, 178, 566-575.

(4) Schmidt, F.; Bernhard, M.; Morell, H.; Pascaly, M. HPPO Process Technology: A novel route to propylene oxide without coproducts. Chim. Oggi 2014, 32, 31-35.

(5) Liu, M.; Ye, X. X.; Liu, Y. Q.; Wang, X. Y.; Wen, Y. Q.; Sun, H. J.; Li, B. J. Highly Selective Epoxidation of Propylene in a LowPressure Continuous Slurry Reactor and the Regeneration of Catalyst. Ind. Eng. Chem. Res. 2015, 54, 5416.

(6) Taramasso, M.; Perego, G.; Notari, B. Preparation of Porous Crystalline Synthetic Material comprised of Silicon and Titanium Oxide. U.S. Patent 1983, 4410501.

(7) Chen, L. Y.; Chuah, G. K.; Jaenicke, S. Propylene epoxidation with hydrogen peroxide catalyzed by molecular sieves, containing framework titanium. J. Mol. Catal. A: Chem. 1998, 132, 281-292.

(8) Liu, X. W.; Wang, X. S.; Guo, X. W.; Li, G. Effect of solvent on the propylene epoxidation over TS-1 catalyst. Catal. Today 2004, 93$95,505-509$.
(9) Lee, H. J.; Shi, T. P.; Busch, D. H.; Subramaniam, B. A greener, pressure intensified propylene epoxidation process with facile product separation. Chem. Eng. Sci. 2007, 62, 7282-7289.

(10) Zuwei, X.; Zhou, N.; Sun, Y.; Li, K. Reaction-controlled phasetransfer catalysis for propylene epoxidation to propylene. Science 2001, 292, 1139-1141.

(11) Kamata, K.; Yonehara, K.; Sumida, V.; Yamaguchi, K.; Hikichi, S.; Mizuno, N. Science 2003, 300, 964.

(12) Weiner, H. Process for epoxidizing olefins with hydrogen peroxide using supported oxo-diperoxo tungstate catalyst complex. U.S. PTO 60/ 999913, 2007.

(13) Lu, X.; Wu, H.; Jiang, J.; He, M.; Wu, V. Selective synthesis of propylene oxide through liquid-phase epoxidation of propylene with $\mathrm{H}_{2} \mathrm{O}_{2}$ over formed Ti-MWW catalyst. J. Catal. 2016, 342, 173-183.

(14) Chen, L. Y.; Chuah, G. K.; Jaenicke, S. Propylene epoxidation with hydrogen peroxide catalyzed by molecular sieves containing framework titanium. J. Mol. Catal. A: Chem. 1998, 132, 281-292.

(15) Chen, C.; Zhao, X.; Chen, J.; Hua, L.; Zhang, R.; Guo, L.; Song, B.; Gan, H.; Hou, Z. Niobium Peroxide-Catalyzed Selective Epoxidation of Allylic Alcohols. ChemCatChem 2014, 6, 3231-3238.

(16) Ramanathan, A.; Maheswari, R.; Subramaniam, B. Facile Styrene Epoxidation with $\mathrm{H}_{2} \mathrm{O}_{2}$ over Novel Niobium Containing Cage Type Mesoporous Silicate, Nb-KIT-5. Top. Catal. 2015, 58, 314-324.

(17) Ahn, S.; Thornburg, N. E.; Li, Z.; Wang, T. C.; Gallington, L. C.; Chapman, K. W.; Notestein, J. M.; Hupp, J. T.; Farha, O. K. Stable metal-organic framework-supported niobium catalysts. Inorg. Chem. 2016, 55, 11954-11961.

(18) Thornburg, N. E.; Nauert, S. L.; Thompson, A. B.; Notestein, J. M. Synthesis-Structure Function Relationships of Silica-Supported Niobium(V) Catalysts for Alkene Epoxidation with $\mathrm{H}_{2} \mathrm{O}_{2}$. ACS Catal. 2016, 6, 6124-6134.

(19) Thornburg, N. E.; Thompson, A. B.; Notestein, J. M. Periodic Trends in Highly Dispersed Groups IV and V Supported Metal Oxide Catalysts for Alkene Epoxidation with $\mathrm{H}_{2} \mathrm{O}_{2}$. ACS Catal. 2015, 5, 5077-5088.

(20) Ivanchikova, I. D.; Maksimchuk, N. V.; Skobelev, I. Y.; Kaichev, V. V.; Kholdeeva, O. A. Mesoporous niobium-silicates prepared by evaporation-induced self-assembly as catalysts for selective oxidations with aqueous $\mathrm{H}_{2} \mathrm{O}_{2}$. J. Catal. 2015, 332, 138-148.

(21) Yan, W.; Ramanathan, A.; Patel, P. D.; Maiti, S. K.; Laird, B. B.; Thompson, W. H.; Subramaniam, B. Mechanistic Insights for Enhancing Activity and Stability of Nb-incorporated Silicates for Selective Ethylene Epoxidation. J. Catal. 2016, 336, 75-84.

(22) Turco, R.; Aronne, A.; Carniti, P.; Gervasini, A.; Minieri, L.; Pernice, P.; Tesser, R.; Vitiello, R.; Di Serio, M. Influence of preparation methods and structure of niobium oxide-based catalysts in the epoxidation reaction. Catal. Today 2015, 254, 99-103.

(23) Tiozzo, C.; Palumbo, C.; Psaro, R.; Bisio, C.; Carniato, F.; Gervasini, A.; Carniti, P.; Guidotti, M. The stability of niobium-silica catalysts in repeated liquid-phase epoxidation tests: A comparative evaluation of in-framework and grafted oxides. Inorg. Chim. Acta 2015, 431, 190-196.

(24) Ramanathan, A.; Zhu, H.; Maheswari, R.; Thapa, P. S.; Subramaniam, B. Comparative Study of Nb-Incorporated Cubic Mesoporous Silicates as Epoxidation Catalysts. Ind. Eng. Chem. Res. 2015, 54, 4236-4242.

(25) Nakajima, K.; Baba, Y.; Noma, R.; Kitano, M.; Kondo, J. N.; Hayashi, S.; Hara, $\mathrm{M} . \mathrm{Nb}_{2} \mathrm{O}_{5} \cdot \mathrm{nH}_{2} \mathrm{O}$ as a heterogeneous catalyst with water-tolerant Lewis acid sites. J. Am. Chem. Soc. 2011, 133, 42244227.

(26) Jehng, J. M.; Wachs, I. E. Structural chemistry and Raman spectra of niobium oxides. Chem. Mater. 1991, 3, 100-107.

(27) Jehng, J. M.; Wachs, I. E. Molecular design of supported niobium oxide catalysts. Catal. Today 1993, 16, 417-426.

(28) Di Serio, M.; Turco, R.; Pernice, P.; Aronne, A.; Sannino, F.; Santacesaria, E. Valuation of $\mathrm{Nb}_{2} \mathrm{O}_{5}-\mathrm{SiO}_{2}$ catalysts in soybean oil epoxidation. Catal. Today 2012, 192, 112-116. 
(29) Yan, W.; Ramanathan, A.; Ghanta, M.; Subramaniam, B. Towards highly selective ethylene epoxidation catalysts using hydrogen peroxide and tungsten- or niobium-incorporated mesoporous silicate (KIT-6). Catal. Sci. Technol. 2014, 4, 4433-4439.

(30) Maiti, S. K.; Ramanathan, A.; Thompson, W. H.; Subramaniam, B. Strategies to Passivate Brønsted Acidity in Nb-TUD-1 Enhance Hydrogen Peroxide Utilization and Reduce Metal Leaching during Ethylene Epoxidation. Ind. Eng. Chem. Res. 2017, 56, 1999-2007.

(31) Ramanathan, A.; Zhu, H.; Maheswari, R.; Subramaniam, B. Remarkable epoxidation activity of neat and carbonized niobium silicates prepared by evaporation-induced self-assembly. Microporous Mesoporous Mater. 2018, 261, 158-163.

(32) Liu, Y.; Murata, K.; Inaba, M. Synthesis and Catalytic Activity of Niobium-Containing Hexagonal Mesoporous Silica. Chem. Lett. 2003, 32, 992-993.

(33) Jin, H.; Subramaniam, B. Homogeneous catalytic hydroformylation of 1-octene in $\mathrm{CO}_{2}$-expanded solvent media. Chem. Eng. Sci. 2004, 59, 4887-4893.

(34) Pham, H. N.; Anderson, A. E.; Johnson, R. L.; Schwartz, T. J.; O’Neill, B. J.; Duan, P.; Schmidt-Rohr, K.; Dumesic, J. A.; Datye, A. K. Carbon Overcoating of Supported Metal Catalysts for Improved Hydrothermal Stability. ACS Catal. 2015, 5, 4546-4555.

(35) Steenbergen, K. G.; Kern, J. L.; Wang, Z.; Thompson, W. H.; Laird, B. B. Tunability of Gas-Expanded Liquids under Confinement: Phase Equilibrium and Transport Properties of Ethylene-Expanded Methanol in Mesoporous Silica. J. Phys. Chem. C 2016, 120, 50105019.

(36) Wróblewska, A.; Makuch, E. Studies on the deactivation of TiMCM-41 catalyst in the process of allyl alcohol epoxidation. Pol. J. Chem. Technol. 2013, 15, 111.

(37) Wróblewska, A.; Makuch, E. Regeneration of the Ti-SBA-15 catalyst used in the process of allyl alcohol epoxidation with hydrogen peroxide. J. Adv. Oxid. Technol. 2014, 17, 44.

(38) Patel, P. D.; Laird, B. B.; Thompson, W. H. A Density Functional Theory Study of Ethylene Epoxidation Catalyzed by Niobium-doped Silica. J. Mol. Catal. A: Chem. 2016, 424, 1-7.

(39) Di Valentin, C.; Gisdakis, P.; Yudanov, I. V.; Rösch, N. Olefin Epoxidation by Peroxo Complexes of $\mathrm{Cr}, \mathrm{Mo}$, and W. A Comparative Density Functional Study. J. Org. Chem. 2000, 65, 2996-3004. 